\title{
INCREASE OF DATA TRANSMISSON EFFICIENCY IN AIRCRAFT SATELLITE MONITORING
}

\author{
A. R. Akzigitov*, A. S. Andronov, R. A. Akzigitov, V. V. Peremishlennikov, D. V. Dmitriev \\ Reshetnev Siberian State University of Science and Technology \\ 31, Krasnoyarsky Rabochy Av., Krasnoyarsk, 660037, Russian Federation \\ *E-mail: aakzigitov88@mail.ru
}

Satellite systems are one of the most common methods of tracking various objects around the world. There are various types of satellite systems for different purposes, but their common feature is data transmission by radio signal. The atmosphere of our planet is nonuniform and its every layer has some characteristics which impede data transmission. In case of insufficient power supply the transmission is practically impossible. That is why there should be worked out special methods and algorithms able to mitigate the atmospheric effect on the signals of the aircraft monitoring devices. The ionosphere, in particular, is the main cause of errors in determining the object's location. For "Iridium" satellites that receive signals from "Iridium 9602" module at frequency of 1616-1625.5 MHz the ionosphere influence induces the alteration of the signal power due to the inhomogeneity of charged particles. The article presents the calculation of attitude data transmission loss in space as they are transmitted by "Iridium 9602" transceiver up to heights of 450, 500 and $600 \mathrm{~km}$.

The proposed method is based on modeling the current map of the total electronic content of the ionosphere. On the basis of this model, a correction of determining the monitored object's location can be made. Today there are several centers performing calculation of total electronic content of the ionosphere. The calculation results are in free access. Thus, having the initial data obtained from the maps of the total electronic content of the ionosphere and the algorithm for making corrections, it is possible to correct the data while solving navigation problems. In particular, the GEMTEC model can be used, as its source of data is a map of total electronic content of the atmosphere.

Keywords: Iridium, monitoring, ionosphere, GEMTEC, error.

Сибирский журнал науки и технологий. 2018. Т. 19, № 2. С. 242-245

\section{ПОВЫШЕНИЕ ЭФФЕКТИВНОСТИ ПЕРЕДАЧИ ДАННЫХ ПРИ СПУТНИКОВОМ МОНИТОРИНГЕ ВОЗДУШНЫХ СУДОВ}

\author{
А. Р. Акзигитов*, А. С. Андронов, Р. А. Акзигитов, В. В. Перемышленников, Д. В. Дмитриев \\ Сибирский государственный университет науки и технологий имени академика М. Ф. Решетнева \\ Российская Федерация, 660037, г. Красноярск, просп. им. газ. «Красноярский рабочий», 31 \\ *E-mail: aakzigitov88@mail.ru
}

\begin{abstract}
Спутниковые системы - один из наиболее распространенных методов отслеживания различных объектов по всему миру. Существуют различные виды спутниковых систем различного назначения, но их общей чертой является передача данных посредством радиосигналов. Атмосфера нашей планеть неоднородна, и каждый ее слой имеет ряд характеристик, которые затрудняют передачу данных, а в случае недостаточной мощности передачи - попросту делают невозможным. Следовательно, необходимо наличие методов и алгоритмов, которые смягчали бы воздействие атмосферы на сигналы устройства мониторинга воздушных судов. В частности, главной причиной погрешности при определении местоположения является слой ионосферы. Для спутников Iridium, осуществляющих прием сигналов от модуля Iridium 9602 с частотой 1616-1625,5 МГи, влияние ионосферы будет заключаться в изменении мощности сигнала из-за неоднородности заряженных частиц. Представлен расчет потерь в свободном пространстве при передаче данных местоположения через трансивер Iridium 9602 на высоты 450, 500 и 600 км.

Предлагаемый для применения метод основан на моделировании текущей карты полного электронного содержания ионосферы. На основе модели вносится коррекиия при определении местоположения объекта мониторинга. На сегоднямний день существуют несколько ичентров, осуществляющих расчет полного электронного содержания ионосферы. Результаты расчетов находятся в свободном доступе. Таким образом, имея исходные данные, полученные по картам полного электронного содержания ионосферы, и алгоритм для коррекции, можно осуществлять поправку данных при решении задачи навигации. Конкретно, предлагается использовать модель GEMTEC, исходными данными для которой является карта полного электронного содержания атмосферы.
\end{abstract}

Ключевые слова: Iridium, мониторинг, ионосфера, GEMTEC, погрешность.

Doi: $10.31772 / 2587-6066-2018-19-2-242-245$ 
Introduction. Satellite systems have found their proper place among modern communication systems. In these systems, the satellite is used as a relay station. These systems are divided into several types depending on the available equipment and the orbit altitude. Depending on the constellation configuration and currently performing hardware, the system can retransmit instantaneously or with a certain delay, if a memory module is available $[1 ; 2]$. However, the common feature of these systems is data transmission in the form of information packages. At present, there is a number of systems using low-orbit satellites. The most common of them are "Iridium", "Globalstar" and "Gonets". The difference between these systems lies in the number of satellites used and the implementation of the constellation configuration. The "Iridium" system is of the greatest interest, as its coverage is almost $100 \%$, which is most preferable for aviation monitoring purposes [2;3]. Monitoring of moving objects is essential for search and rescue activities; quick location of aircraft crash site allows not only to save human life, but also to significantly reduce the cost of rescue operation. However, the use of any satellite system presents certain challenges, for instance, ensuring the reliability of data transmission. The main factors affecting the reliability are natural and technical. Natural factors are the influence of the atmosphere and other natural effects. Technical factors are mainly the malfunction of equipment and incorrect decoding. There is a need to eliminate errors and mistakes and provide a balanced transmission line "Aircraft Iridium - Earth" with a sufficient supply of power potential for transmission.

Technical factors and ionospheric effects. Malfunction of the computer or of the installed program is the major factor that influences the reliability of data transmission. Modern systems, such as "Iridium", use a variety of protocols for data transfer; that requires the use of high-volume programs for protocol decoding. Generally, the solution of this problem is installation of advanced software with incorporated security and control systems. The effects are caused by the presence of charged particles, namely ions in the atmosphere. These particles cause signal delay [3-5]. The extent of delay varies depending on solar activity and location. The density of ions in the atmosphere is non-uniform, which makes it impossible to calculate the precise effect. In case of the "Iridium" system the frequency range of which is within the L-band, ionospheric effects considerably influence the search of the satellite location [6].

Tropospheric effects. Troposphere is the layer of the atmosphere at altitudes up to $10 \mathrm{~km}$ above sea level. It is mainly this layer causes attenuation of the signal due to the existence of the effect called "eye of troposphere", namely presence of water vapour, rain and clouds causing the attenuation [6].

"Iridium" power calculation. "Iridium 9602" transceiver is used for data transmission to satellite. The transceiver is a part of the device being developed under surveillance of the Ministry of Emergency Situations, "Iridium" is a series device using GPS technology [7-9]. Further technical calculations and solutions of the abovementioned problems related to ensuring the reliability of the transmission for devices of this type will also be cited. Since the calculation of power characteristics involves numerous variables caused by nonuniformity of the atmosphere, we will regard it as uniform, and the effect of the Earth as negligible. Then the total feeder loss will not exceed $2 \mathrm{~dB}$. The following two basic equations describe the power balance. Equivalent isotropically radiated power $[10 ; 11]$ :

$$
P_{\ni}=G_{\Pi}^{*}+10 \lg \left(P_{\Pi} \eta_{\mathrm{H}}\right),
$$

where $P_{\Pi}$ is the power of the transmitter; $\eta_{\mathrm{H}}$ is the power transmission coefficient of the transmitting station feeder path; $G_{\Pi}{ }^{*}$ is the gain of the transmitting antenna in $\mathrm{dB}$. The quality factor of the receiving station $[11 ; 12]$ :

$$
\frac{G}{T}=G_{\Pi P}^{*}+10 \lg T_{\Sigma},
$$

where $T_{\Sigma}$ is the total equivalent noise temperature of the receiving station reduced to the antenna input; $G_{\Pi \mathrm{P}}{ }^{*}$ is the receiving antenna gain in $\mathrm{dB}$. These two expressions fully characterise the communication line. Accordingly, the frequency attenuation lines appear as in the following figure.

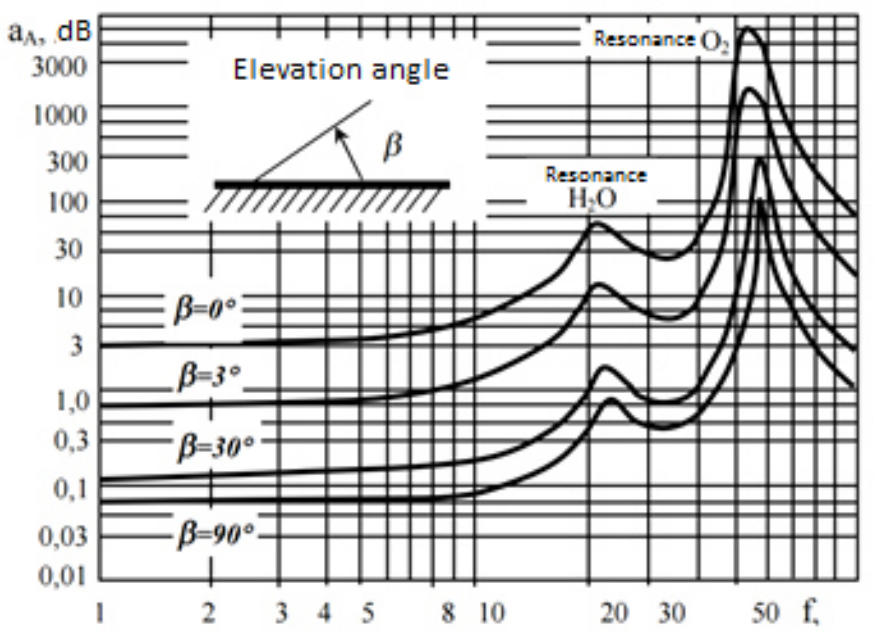

Frequency characteristics of attenuation in the atmosphere

Частотные характеристики затухания в атмосфере 
These expressions determine the main performance characteristics of the equipment, specifying the potential power reserve for data transmission [12]. For the monitoring device developed under supervision of the Ministry of Emergency Situations, the loss figures in different satellite orbits are given in table, assuming that the transmission power of "Iridium 9602" transceiver equals to $1 \mathrm{~dB} \cdot \mathrm{W}$; that was calculated using the equation $[12 ; 13]$ :

$$
P_{\Pi}=\eta_{\mathrm{H}} \cdot P_{\mathrm{B}} \cdot
$$

Space loss of "Iridium9602" transceiver Iridium 9602

\begin{tabular}{|c|c|}
\hline$r, \mathrm{~km}$ & $L, \mathrm{~dB}$ \\
\hline 450 & -149.93 \\
\hline 500 & -150.85 \\
\hline 600 & -152.43 \\
\hline
\end{tabular}

Error reduction methods. The use of the GEMTEC model is one of the solutions. The method is based on application of natural orthogonal functions, the source data of which is in the distribution of electronic data loss coefficient in the atmosphere [13]. This method involves the consideration of variables and their complete account for the navigation system. The variables' values are transmitted together with the message; further corrections are made by the appropriate algorithm at least once every 6 days. Let us consider the main equations of this method. Let $N$ be a set of measurements for $f(n, x)$ value, depending on a set of factors. In each set, the variable $x$ takes a certain value, and other factors are taken as constants. The expansion for each set takes the form of the equation [14]:

$$
f^{n}(x)=\sum_{i=1}^{i_{0}} b_{i}^{n} y_{i}(x)
$$

where $y_{i}(x)$ are natural orthogonal functions identical for all datasets, and $b_{i}^{n}$ are expansion coefficients that characterise the dataset of $n$ number and independent of $x$. The coefficients $b_{i}^{n}$ supply the values of all factors except the $x$ factor. The system of orthogonal functions in general can be found by means of matrixes, under condition $A y_{i}=\lambda_{i} y_{i}$, where $y_{i}$ are orthogonal functions and $A$ is a matrix size of $k_{0} * k_{0}[14]$ :

$$
\begin{gathered}
A=\left\{A_{\text {кр }}\right\}=\left\{\sum_{n=1}^{N} f_{k}^{n} f_{p}^{n}\right\}= \\
=\left\{\begin{array}{ccc}
\sum_{n=1}^{N} f_{1}^{n} f_{1}^{n} & \sum_{n=1}^{N} f_{1}^{n} f_{2}^{n} & \sum_{n=1}^{N} f_{1}^{n} f_{k_{0}}{ }^{n} \\
\cdots & \ldots & \ldots \\
\sum_{n=1}^{N} f_{k_{0}}{ }^{n} f_{1}^{n} & \sum_{n=1}^{N} f_{k_{0}}{ }^{n} f_{2}^{n} & \sum_{n=1}^{N} f_{k_{0}}{ }^{n} f_{k_{0}}{ }^{n}
\end{array}\right\} .
\end{gathered}
$$

The second method to be analyzed here is a graphic method. This method implies using root mean-square values of the carrier and the code. When we add the averaging of the code range and carrier phase, the main equation takes the form [15]:

$$
P=\frac{P_{r}+\Phi_{L 1}}{2},
$$

where $P_{r}$ is the value of pseudo-range; $\Phi_{L 1}$ is the phase range of carrier frequency $L_{1}$. In this equation the combined measurement no longer depends on the ionospheric delay and shows the noise level. However, there is a drawback code measurement errors considerably affect the final results. This method is preferable in real- time mode or in the processing of already obtained data [15].

Conclusion. With allowance for the operation of transmitting and receiving equipment in balanced radio link, the average deviation of the object's positioning data will have an error of $\pm 50 \mathrm{~m}$. With the use of error mitigation techniques, errors in the data on the Earth artificial satellite's actual position will be less in value. The reliability of the data will be higher due to the minimum of losses in information packages and shorter delay time on the "Satellite-Aircraft" link. Together with the application of GEMTEC method, deviations will be $\pm 5 \mathrm{~m}$. It is possible to minimise losses and delays using the offered operational model, allowing for the use of additional differentiation algorithms to make the model work in real- time mode. The graphic method is more suitable for research analysis of the data already available.

\section{References}

1. Abolits A. I. Sistemy sputnikovoy svyazi. Osnovy strukturno-parametricheskoy teorii i effektivnost' [Satellite communication systems. Fundamentals of structuralparametric theory and efficiency]. Moscow, ITIS Publ., 2004, 426 p.

2. IRIDIUM. Uslugi peredachi dannykh kompanii Iridium. Belaya kniga. Versiya 1.1.2 [IRIDIUM. Data transmission services of "Iridium". White Paper. Version 1.1.2] (In Russ.). Available at: http://iridium.steccom.ru/ wp-content/uploads/2012/09/Iridium-Data-Services-WhitePaper-11.1.2_RU.pdf (accessed 15.04.2016).

3. Lazarev A. I., Nechaev E. E. [Status and development of satellite communication and navigation systems]. Nauchnyy vestnik Moskovskogo gosudarstvennogo tekhnicheskogo universiteta grazhdanskoy aviatsii. 2010, No. 159, P. 32-43 (In Russ.).

4. Multi-Link Iridium Satellite Data Communication System. Available at: http://citeseerx.ist.psu.edu/viewdoc/ download?doi=10.1.1.129.3230\&rep=rep1\&type $=$ pdf (accessed 17.04.2016).

5. Error Sources. Available at: http://www.novatel.com/an-introduction-tognss/chapter-4gnss-error-sources/error-sources/ (accessed 17.04.2016).

6. Hutorova O. G. Zondirovanie atmosfery i ionosfery radiosignalami sputnikovykh navigatsionnykh system [Sounding of the atmosphere and ionosphere with radio signals of satellite navigation systems]. Kazan, Kazan Federal University Publ., 2011, 117 p.

7. Tanjila F. Performance Analysis of Low Earth Orbit (LEO) Satellite Link in the presence of Elevation Angle, Fading, And Shadowing. Bangladesh, BRAC University Publ., 2009, 66 p.

8. Zaharov F. N., Krutikov M. V. [Comparison of accuracy of navigation signal time delay in different models of refractive index vertical profile]. Doklady Tomskogo gosudarstvennogo universiteta system upravleniya $i$ ra- 
dioehlektroniki [Reports of Tomsk state university of control systems and radio electronics]. Tomsk, TUSUR, 2014, P. 7-12 (In Russ.).

9. Kacura A. V., Akzigiov A. R., Andronov A. S., Strokov D. E. et al. [Development of onboard device for aircraft satellite monitoring]. Vestnik SibGAU. 2016, Vol. 17, No. 1, P. 125-130 (In Russ.).

10. Tsisar L. [The best satellite communication expands standards]. Tekhnologii $i$ sredstva svyazi. 2008, No. 64, P. 40-42 (In Russ.).

11. Iridium 9602 SBD Transceiver Developer's Guide. Revision 6.0. Available at: http://nearspace.ru/ doc/Iridium-9602-SBD-Transceiver-Product-DevelopersGuide.pdf (accessed 18.04.2016).

12. Dorezyuk N. I. [Recommendations for the choice and operation of feeders]. INFORMOST - radioelektronika i telekommunikatsii. 2002, No. 5(23), P. 1-8 (In Russ.).

13. Bylinin K. E., Gorbachev O. A., Ivanov V. B., Gefan G. D. [Global empirical model of ionospheric error correction in satellite navigation systems]. Nauchnyy vestnik MSTU CA. 2011, No. 171, P. 151-156 (In Russ.).

14. Najman P. Nature of the GNSS ionospheric error and modeling of mid-latitudes ionospheric structures in relation to the space weather. Kvalifacijski Doktorski Ispit, August 2012.

15. Ivanov V. B., Gorbacev O. A., Gefan G. D. The GEMTEC Model: Assessment of Quality of Ionospheric Correction in Satellite Radio Navigation Systems. Consumer Electronics Times. 2012, Vol. 1, No. 3, P. 43-46.

\section{Библиографические ссылки}

1. Аболиц А. И. Системы спутниковой связи. Основы структурно-параметрической теории и эффективность. М. : ИТИС, 2004. 426 с.

2. IRIDIUM. Услуги передачи данных компании Iridium. Белая книга. Версия 1.1.2 [Электронный реcypc]. URL: http://iridium.steccom.ru/wp-content/uploads/ 2012/09/Iridium-Data-Services-White-Paper-11.1.2_RU.pdf (дата обращения: 15.04.2016).

3. Лазарев А. И., Нечаев Е. Е. Состояние и развитие спутниковых систем связи и навигации // Научный вестник Московского государственного технического университета гражданской авиации. 2010. № 159. С. 32-43.

4. Multi-Link Iridium Satellite Data Communication System [Электронный pecypc]. URL: http://citeseerx.ist.psu.edu/viewdoc/download?doi=10.1.1 .129.3230\&rep=rep1\&type=pdf (дата обращения: 17.04.2016).

5. Error Sources [Электронный pecypc]. URL: http://www.novatel.com/an-introduction-to-gnss/chapter4-gnss-error-sources/error-sources/ (дата обращения: 17.04.2016).

6. Хуторова О. Г. Зондирование атмосферы и ионосферы радиосигналами спутниковых навигационных систем. Казань : Изд-во Казан. федер. ун-та, 2011. $117 \mathrm{c}$.

7. Tanjila F. Performance Analysis of Low Earth Orbit (LEO) Satellite Link in the presence of Elevation Angle, Fading, and Shadowing. Bangladesh : BRAC University publ., 2009. 66 p.

8. Захаров Ф. Н., Крутиков М. В. Сравнение точности времени задержки навигационных сигналов при использовании различных моделей высотного профиля индекса преломления // Доклады Томского государственного университета систем управления и радиоэлектроники. 2014. № 2 (32).С. 7-12.

9. Разработка бортового устройства спутникового мониторинга воздушных судов / А. В. Кацура [и др.] // Вестник СибГАУ. 2016. Т. 17, № 1. С. 125-130.

10. Цисар Л. Лучшая спутниковая связь расширяет стандарты // Технологии и средства связи. 2008. № 64. C. $40-42$.

11. Iridium 9602 SBD Transceiver Developer's Guide. Revision 6.0 [Электронный pecypc]. URL: http://nearspace.ru/doc/Iridium-9602-SBD-TransceiverProductDevelopersGuide.pdf (дата обращения: 18.04.2016).

12. Дорезюк Н. И. Рекомендации по выбору и эксплуатации фидеров // ИНФОРМОСТ - радиоэлектроника и телекоммуникации. 2002. № 5(23). С. 1-8.

13. Глобальная эмпирическая модель коррекции ионосферной погрешности спутниковых навигационных систем / К. Е. Былинин [и др.] // Научный вестник МГТУ ГА. 2011. № 171. С. 151-156.

14. Najman P. Nature of the GNSS ionospheric error and modeling of mid-latitudes ionospheric structures in relation to the space weather. Kvalifacijski Doktorski Ispit. 2012.

15. Ivanov V. B., Gorbacev O. A., Gefan G. D. The GEMTEC Model: Assessment of Quality of Ionospheric Correction in Satellite Radio Navigation Systems // Consumer Electronics Times. 2012. Vol. 1, № 3. P. 43-46.

(C) Akzigitov A. R., Andronov A. S., Akzigitov R. A., Peremishlennikov V. V., Dmitriev D. V., 2018 